\title{
Peran Kualitas Auditor pada Determinan Tax Avoidance Perusahaan Customer Goods
}

${ }^{1}$ Universitas Pancasila, DKI Jakarta, Jakarta Selatan

${ }^{2}$ Universitas Pancasila, DKI Jakarta, Jakarta Selatan

${ }^{3}$ Universitas Pancasila, DKI Jakarta, Jakarta Selatan

\section{A R T I C L E I N F O JEL Classification: M42; H25}

Key words: profitability, leverage, institutional ownership, company risk, tax avidance, audit quality

\begin{abstract}
Tax avoidance is a business transaction designed to reduce the tax burden by exploiting loopholes in a country's tax laws so that tax experts declare it legal because they don't violate tax regulations. Many companies that are more interested in maximizing profits, strict efficiency guidelines on tax spending are widely applied by companies. The cause of low tax revenues is low tax compliance. Tax compliance remains low because taxpayers do not pay their tax obligations, and because taxpayers pay less than what they should. This study aims to analyze the effect of profitability, leverage, institutional ownership, and company risk on tax avoidance. To analyze the effect of profitability, leverage, institutional ownership, and company risk on tax avoidance with audit quality as a moderator. The method applied in this research is the quantitative method and the form of explanative research. The population in this research is the number of consumer goods companies listed on the Indonesia Stock Exchange for the period 2016-2019. The sampling method in this study using purposive sampling. The data analysis method of this research is using moderation regression model analysis with the help of the SPSS 24 program. The results of this study found that profitability, institutional ownership, and company risk have no effect on tax avoidance of customer good companies listed at the IDX for the 2016-2019 period. Leverage has a significant effect on tax avoidance of consumer goods companies listed at the Indonesia Stock Exchange for the period 2016-2019. Audit quality moderated the effect of profitability, leverage, and institutional ownership on tax avoidance of consumer goods companies listed at the Indonesia Stock Exchange for the period 2016-2019. Audit quality does not moderate the impact of Company Risk on Tax Avoidance of Consumer Goods companies listed at the Indonesia Stock Exchange for the period 2016-2019.
\end{abstract}

\section{ABSTRAK}

Penghindaran pajak merupakan transaksi bisnis yang dirancang guna mengurangi beban pajak melalui pemanfaatan celah dalam undang-undang perpajakan suatu negara agar pakar perpajakan menyatakan legal karena tidak melanggar aturan perpajakan. Banyak perusahaan yang lebih tertarik untuk memaksimalkan keuntungan, penerapan efisiensi yang ketat pada pengeluaran pajak banyak diterapkan perusahaan. Penyebab rendahnya penerimaan pajak ialah masih rendahnya kepatuhan pajak. Kepatuhan pajak tetap rendah karena tidak membayar kewajiban pajak oleh wajib pajak, serta karena wajib pajak membayar kurang dari yang seharusnya dibayar. Penelitian ini bertujuan untuk menganalisa pengaruh profitabilitas, leverage, kepemilikan institusional, dan risiko perusahaan terhadap tax avoidance. Untuk menganalisa pengaruh profitabilitas, leverage, kepemilikan institusional, dan risiko perusahaan terhadap tax avoidance dengan kualitas audit sebagai pemoderasi. Metode yang diterapkan dalam penelitian ini ialah metode kuantitatif dan bentuk penelitian eksplanatif. Populasi dalam penelitian ini merupakan jumlah perusahaan Consumer Goods yang terdaftar di Bursa Efek Indonesia periode 2016-2019. Metode pengambilan sampel dalam penelitian ini menggunakan purposive sampling. Metode analisis data penelitian ini menggunakan analisis model regresi moderasi dengan bantuan program SPSS 24. Hasil penelitian ini menunjukkan bahwa profitabilitas, kepemilikan institusional, dan risiko perusahaan tidak berpengaruh terhadap tax avoidance pada perusahaan customer good yang terdaftar di BEI periode 2016-2019. Leverage berpengaruh signifikan terhadap tax avoidance pada perusahaan Consumer Goods yang terdaftar di Bursa Efek Indonesia periode 20162019. Kualitas audit terbukti memoderasi pengaruh profitabilitas, leverage, dan kepemilikan institusional terhadap tax avoidance pada perusahaan Consumer Goods yang terdaftar di Bursa Efek Indonesia periode 2016-2019. Kualitas Audit terbukti tidak memoderasi pengaruh Risiko Perusahaan terhadap Tax Avoidance pada perusahaan Consumer Goods yang terdaftar di Bursa Efek Indonesia periode 2016-2019. 


\section{PENDAHULUAN}

Memungut pajak tidaklah mudah. Bagi negara, pajak adalah sumber pendapatan. Tetapi dengan perusahaan semuanya berbeda. Untuk perusahaan, ini adalah biaya yang dapat mengurangi jumlah laba. Dalam praktiknya, terdapat perbedaan persentase antara wajib pajak dan negara. Perusahaan berupaya menyetorkan pajaknya seminimal mungkin, karena menyetorkan pajak tersebut artinya mengurangi peluang ekonomi bagi perusahaan. Kondisi ini membuat banyak perusahaan mencari cara untuk meminimalkan beban pajaknya. Ada beberapa cara untuk meminimalisir beban pajak, dari yang masih tunduk pada aturan perpajakan hingga yang melanggar aturan perpajakan. Meminimalkan kewajiban perpajakan yang tidak melanggar hukum umumnya dikenal dengan istilah penghindaran pajak.

Penghindaran pajak ialah transaksi bisnis yang dirancang guna mengurangi beban pajak melalui pemanfaatan celah dalam undangundang perpajakan suatu negara agar pakar perpajakan menyatakan legal karena tidak melanggar aturan perpajakan. Banyak perusahaan yang lebih tertarik untuk memaksimalkan keuntungan, penerepan efisiensi yang ketat pada pengeluaran pajak banyak diterapkan perusahaan. Akan tetapi biasanya tindakan tersebut tidak dipertimbangkan untuk kemungkinan mengumpulkan pengeluaran pajak dalam pemeriksaan pajak. Tindakan pajak yang agresif dapat mengakibatkan denda atau sanksi oleh otoritas pajak, serta penurunan nilai saham perusahaan. Hal ini semakin meningkatkan risiko bagi perusahaan, yang niscaya akan mempengaruhi kelancaran usahanya. Penghindaran pajak merupakan upaya meringankan beban pajak dan dapat berdampak pada pemotongan pajak badan yang tidak melanggar hukum dalam praktiknya (Charisma dan Dwimulyani, 2019).

Dalam empat tahun terakhir, penerimaan pemerintah dalam Anggaran Pendapatan dan Belanja Negara (APBN) tidak pernah tercapai, terlebih dari sektor perpajakan. Seperti ditunjukan tabel 1.1.

Tabel 1.1 Data Penerimaan Pajak (Dalam Triliun Rupiah)

\begin{tabular}{ccll}
\hline Tahun & Target & Realisasi & Capaian \\
\hline 2016 & 1355,20 & 1505,73 & $81,59 \%$ \\
2017 & 1283,57 & 1151,03 & $89,67 \%$ \\
2018 & 1424,00 & 1315,51 & $92,24 \%$ \\
2019 & 1578,00 & 1332,00 & $84,4 \%$ \\
\hline
\end{tabular}

*Sumber: DJP (2019)

Mulai 2018, penerimaan pajak pemerintah mencapai Rp. 1.424,00 triliun, penerimaan pajak hingga Desember 2018 mencapai Rp. 1.333,51 triliun adalah sebesar 92,24\% dari target. Serta dari target sebesar Rp. 1.578 triliun di tahun 2019, penerimaan pajak hingga 2019 Desember jumlahnya hanya Rp. 1.332 triliun, yang berarti $84,4 \%$ dari target. Berdasarkan kemajuan selama empat tahun terakhir, tampaknya target tersebut tidak tercapai. Sama seperti pada tahun 2017, ketika biaya tersebut direalisasikan hanya untuk Rp. 1.151,03 triliun dari Rp. 1.283,57 triliun yang mencapai $89,67 \%$.

Penyebab rendahnya penerimaan pajak ialah masih rendahnya kepatuhan pajak. Kepatuhan pajak tetap rendah karena tidak membayar kewajiban pajak oleh wajib pajak, serta karena wajib pajak membayar kurang dari yang seharusnya dibayar. Hal ini terlihat dari nilai rata-rata Tax Avoidance perusahaan consumer goods tahun 2016-2018. 
Tabel 1.2 Kinerja pajak 2016-2019 (\%)

\begin{tabular}{cc}
\hline Tahun & Tax Avoidance \\
\hline 2016 & 0.249 \\
2017 & 0.247 \\
2018 & 0.257 \\
2019 & 0.269 \\
\hline
\end{tabular}

*Sumber: DJP (2019)

Gambar 1.1 Grafik Tax Avoidance

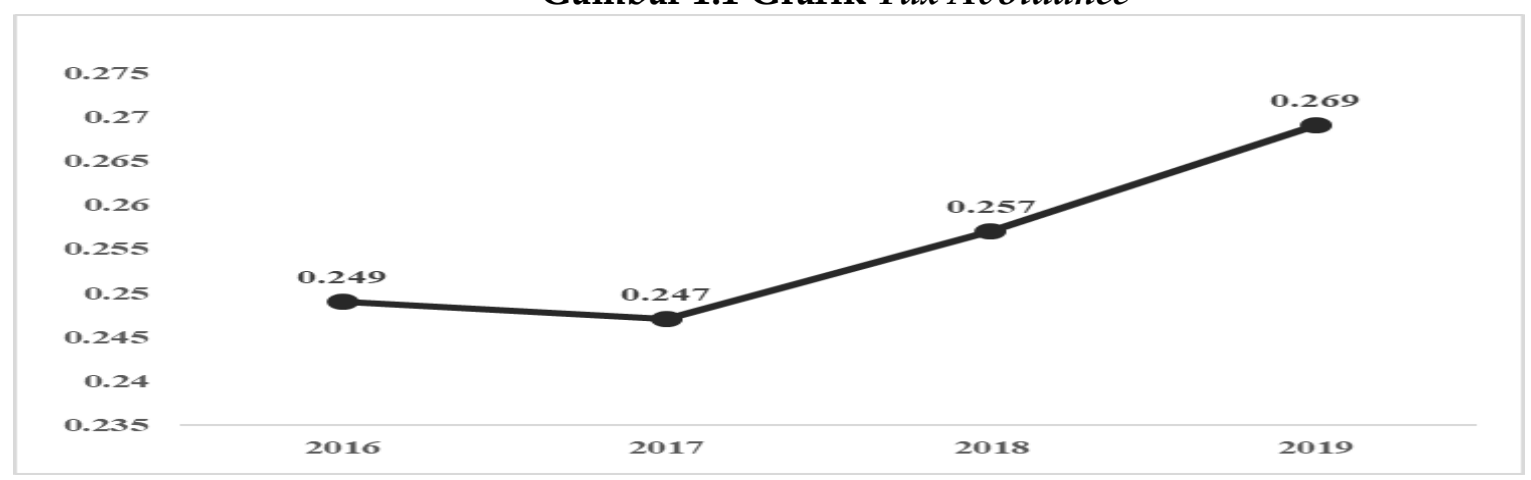

Gambar 1.1 di atas menjelaskan bahwa rata-rata nilai tax avoidance perusahaan consumer goods untuk tahun 2016 dan 2017 masih di bawah $25 \%$, dan pada tahun 2018 dan 2019 yang memiliki nilai $>25 \%$. Ini menjelaskan hal itu pada tahun 2016 dan tahun 2017 tarif pajak efektif untuk perusahaan barang konsumsi masing-masing adalah $24,9 \%$ dan $24,7 \%$. Hal ini memperlihatkan jika rata-rata perusahaan dapat mengurangi beban pajaknya atau masih dibawah tarif pajak badan yang berlaku (25\%). Dengan demikian, penggelapan pajak masih terjadi di perusahaan barang konsumsi. Wajib pajak melakukan praktik penghindaran pajak guna mengurangi beban pajak dimana hal itu ditanggung oleh perusahaan selaku wajib pajak. Perencanaan pajak yang agresif melibatkan aktivitas yang diizinkan berdasarkan undang-undang perpajakan yang berlaku dan yang melanggar aturan pajak yang berlaku.

Ada beberapa faktor yang mempengaruhi manajemen untuk menghindari pajak, antara lain profitabilitas, leverage, kepemilikan institusional, dan risiko perusahaan. Indeks profitabilitas ialah salah satu bentuk penilaian manajemen dalam pengelolaan aset perusahaan yang tercermin dari manfaat yang dihasilkan. Artinya indeks laba menunjukkan kemampuan perusahaan dalam memperoleh laba dengan menggunakan aset dan modal perusahaan (Rozak et al, 2018). Selain itu, indeks profitabilitas Janrosl dan Efriyenti (2018) merupakan indeks untuk mengukur laba perusahaan. Hubungan tersebut juga menunjukkan tingkat efisiensi manajemen perusahaan. Hal ini ditunjukkan dengan keuntungan dari penjualan dan pendapatan investasi.

Leverage (struktur hutang) merupakan rasio yang meperlihatkan jumlah hutang yang harus dibiayai perusahaan untuk operasinya. Bisnis dapat menggunakan dana pinjaman untuk memenuhi kebutuhan operasi dan investasi mereka. Namun, biaya tetap (tingkat pengembalian tetap) akan dibebankan pada hutang, yang disebut bunga. Semakin tinggi hutang, semakin rendah laba kena pajak karena keringanan pajak hutang yang lebih tinggi. Ini mengarah pada penggunaan yang lebih tinggi dari hutang perusahaan. Karenanya, saat suatu perusahaan memiliki hutang yang besar, semakin rendah juga pajak yang disetorkan. Menurut Putri dan Putra (2017), salah satu alasan keuangan yang menjadi ciri rasio hutang terhadap ekuitas suatu perusahaan merupakan leverage. Kepemilikan institusional adalah kepemilikan saham pada negara, lembaga 
keuangan, badan hukum, lembaga asing, perwalian dan lembaga lainnya. Lembagalembaga tersebut memiliki kekuatan untuk memantau efektivitas pengelolaan (Ngadiman dan Puspitasari, 2014). Perusahaan, sebagai pemegang saham, disebut dapat mencari-cari kesalahan yang ada. Ini karena pengusaha lebih berpengetahuan daripada investor perseorangan.

Risiko perusahaan dikatakan menjadi factor yang dapat mempengaruhi penghindaran pajak. Coles et al. (2004) berpendapat bahwa risiko perusahaan mencerminkan kebijakan yang diambil oleh manajer perusahaan dan oleh karena itu dapat menjadi indikator sifat pengambilan risiko atau penghindaran risiko.
Risiko perusahaan adalah suatu kondisi di mana kemungkinan operasi perusahaan kurang dari yang diharapkan karena kondisi masa depan tidak ideal. Masalah dengan Perusahaan adalah perbedaan dana Perusahaan dapat ditentukan dengan menggunakan model dua dimensi. Dengan demikian, masalah perusahaan yang dapat diterjemahkan ke dalam anggaran atau variabilitas, bahkan jika perbedaannya lebih sedikit dalam perencanaan (divergensi risiko) atau lebih tinggi dalam perencanaan (mungkin lebih tinggi), memodifikasi pendapatan perusahaan meningkatkan risiko perusahaan ada (Damayanti dan Susanto, 2015).

\section{Gambar 1.2 Rata-Rata Peningkatan Beban Pajak Perusahaan Consumer Goods}

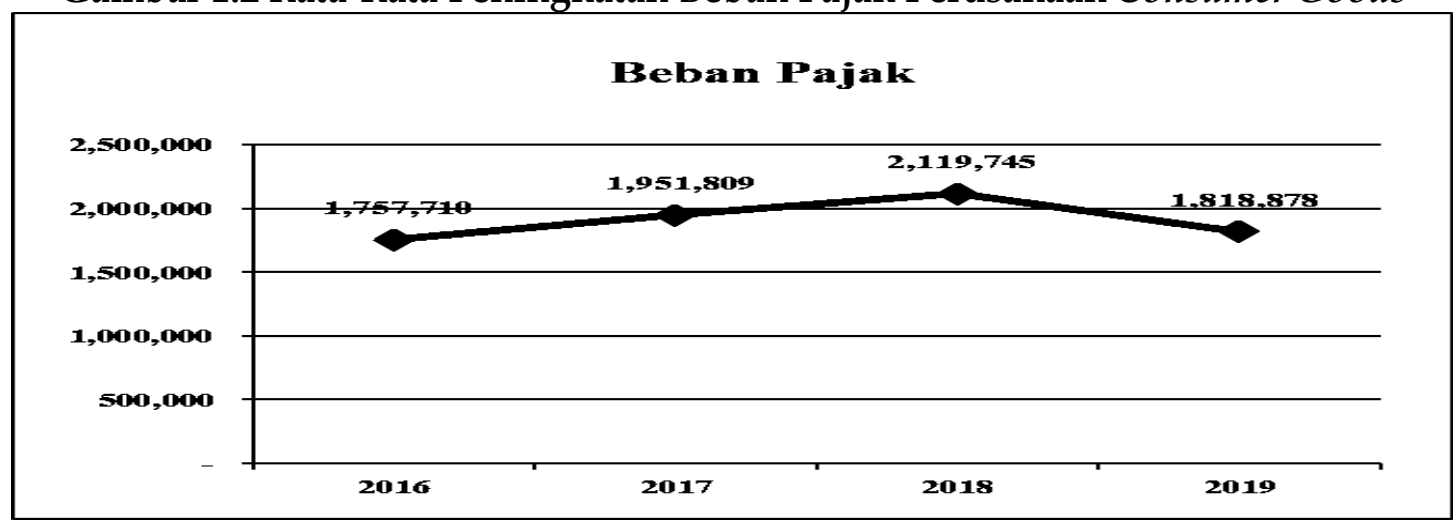

Sumber: BEI (2019)

\section{Gambar 1.3 Rata-Rata Peningkatan Laba Bersih Consumer Goods Tahun 2016 sampai dengan} Tahun 2019 (disajikan dalam juta rupiah)

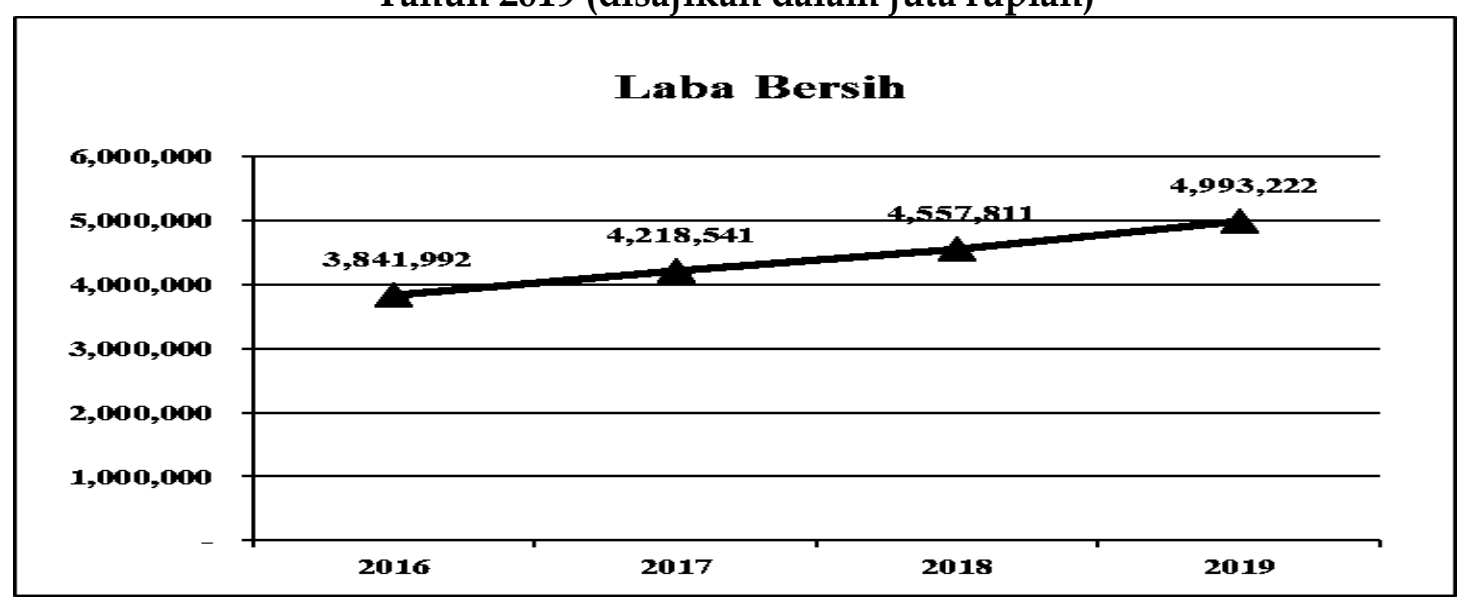

Sumber: BEI (2018)

Berdasarkan Gambar 1.3, terlihat secara rata-rata pajak penghasilan perusahaan consumer goods mencapai di atas 1 triliuan rupiah per tahun, Nilai pembayaran pajak ini 
memberikan kontribusi yang signifikan kepada penerimaan negara. Namun tingkat pertumbuhan pembayaran pajak ini masih memiliki gap yang cukup besar jika dibandingkan dengan pendapatan rata-rata laba bersih perusahaan consumer goods yang mencapai di atas 4 triliuan rupiah tahun 20172019. Kondisi ini memumculkan spekulasi bahwa terdapat indikasi perusahaan consumer goods telah melakukan praktik penghindaran pajak.

Beberapa faktor empiris yang memberikan pengaruh penghindaran pajak telah dilakukan, antara lain: penelitian Zahirah (2017) yang menyatakan bahwa leverage memiliki pengaruh positif terhadap penghindaran pajak, kepemilikan institusional memiliki pengaruh positif terhadap penghindaran pajak, dan Sari (2018) profitabilitas memiliki pengaruh positif terhadap penghindaran pajak. Namun hal ini berbeda dengan penelitian Arianandini dan Ramanta (2018) yang menunjukkan bahwa profitabilitas memiliki pengaruh negatif signifikan terhadap penghindaran pajak, leverage tidak berpengaruh signifikan terhadap penghindaran pajak, dan kepemilikan institusional tidak berpengaruh signifikan terhadap penghindaran pajak. pembayaran pajak. Anggara dan Mirah (2019) juga menemukan bahwa leverage tidak mempengaruhi penggelapan pajak. Wijayanti dan Markusiwati (2017) menemukan bahwa kepemilikan institusional tidak mempengaruhi penggelapan pajak. Dewi dan Sari (2015) menunjukkan risiko perusahaan memiliki pengaruh negatif terhadap penggelepan, sedangkan Damayanti dan Susanto (2015) mengemukakan jika risiko perusahaan efektif untuk penggelapan pajak. Selain itu, menurut Jihene dan Moez (2019), kualitas audit memegang peranan yang sangat penting sebagai variabel kontrol dalam menentukan hubungan antara penghindaran pajak dengan variabel independen.

Berdasarkan hasil telaah beberapa penelitian di atas, dapat diketahui masih terdapat gap research yang cukup lebar antara satu peneliti dengan peneliti lainnya, disamping itu, masih terbatas penelitian tentang tax avoidance yang melibatkan kualitas audit sebagai variabel pemoderasi. Hal ini yang $m$ njadi salah satu dasar pertimbangan peneliti tertarik meneliti mengenai pengaruh profitabilitas, leverage, kepemilikan institusional dan risiko perusahaan terhadap tax avoidance dengan kualitas auditor sebagai pemoderasi pada perusahaan consumer goods. Perusahaan consumer goods ditentukan sebagai subjek penelitian, karena memperhitungkan hasil sektor konsumer emiten tahun 2018 dianggap positif. Kementerian Perindustrian dan Perdagangan mencatat, industri makanan dan minuman dapat tumbuh 7,91 persen sepanjang tahun, sedangkan laju pertumbuhan ekonomi negara itu melebihi 5,17 persen. Industri pengolahan makanan menjadi satu sektor yang mendukung peningkatan nilai investasi di tahun 2018. Itu berjumlah Rp. 56,60 triliun. Sejumlah emiten di sektor konsumen berkinerja baik, termasuk pertumbuhan laba. Sedangkan pada 2019 pemilu juga memberikan semangat kepada emiten di sektor konsumen. Valdi Kurniawan (2019), seorang analis di Phintraco Sekuritas, mengatakan: "Secara keseluruhan, prospek sektor barang konsumsi pada 2019 mereka masih cukup menarik. Potensi industri makanan dan minuman Indonesia dapat menjadi yang terdepan karena pasokan yang tinggi dan basis konsumen yang besar. Untuk itu, salah satu kunci daya saing di sektor ini adalah inovasi dan keamanan pangan (Markeeters, 2019). Peneliti memilih perusahaan consumer goods sebagai obbjek penelitian, dikarenakan perusahaan consumer goods adalah perusahaan yang memiliki perhatian positif. Produk perusahaan sektor konsumen merupakan kebutuhan pokok yang dibutuhkan banyak orang.

\section{TELAAH TEORI DAN PENGEMBANGAN HIPOTESIS}

\subsection{Pengaruh Profitabilitas Terhadap Tax Avoidance}

Menurut teori keagenan, beban pajak akan diatur sedemikian rupa agar tidak mengimbangi pekerjaannya akibat rendahnya pendapatan perusahaan akibat beban pajak yang lebih rendah. Artinya, sumber daya 
perusahaan dapat digunakan oleh para agen untuk meningkatkan remunerasi atas kerja para agen, yaitu mengurangi beban pajak pada perusahaan guna meningkatkan produktivitas yang kompleks. Perusahaan yang sangat menguntungkan memiliki peluang untuk menghindari pembayaran pajak, yang dapat mengurangi kewajiban pajak mereka (Chen et al. 2010).

Menurut Sari (2018), profitabilitas memiliki pengaruh positif signifikan terhadap penggelapan pajak. Berarti keuntungan yang lebih tinggi akan mempengaruhi tingkat penghindaran pajak yang lebih tinggi. Hal tersebut dibenarkan oleh peneliti Susanti (2018) yang menunjukkan bahwa pengecualian memiliki pengaruh yang signifikan terhadap penggelapan pajak.

Semakin tinggi profitabiiltas, semakin tinggi laba perusahaan. Seiring dengan peningkatan laba perusahaan, begitu pula pajak penghasilan. Perusahaan yang sangat menguntungkan memiliki kesempatan untuk mendorong diri mereka sendiri ke perencanaan pajak, yang dapat mengurangi jumlah kewajiban pajak. Perusahaan dengan perencanaan pajak yang baik cenderung menghindari pembayaran pajak. Dari penjelasan diatas, hipotesis pertama adalah:

H1: Profitabilitas berpengaruh positif terhadap tax avoidance

\subsection{Pengaruh Leverage Terhadap Tax Avoid- ance}

Teori kompensasi menjelaskan bahwa perusahaan akan memiliki hutang terbaik dan pajak atas hutang tersebut sama dengan biaya bank ditambah biaya badan, yang berutang lebih banyak. Artinya alternatifnya adalah menabung dalam hutang dan pajak. Selain itu, perspektif bisnis menunjukkan bahwa penggunaan hutang yang berlebihan juga akan berdampak negatif bagi perusahaan, penggunaan hutang yang berlebihan akan menghilangkan manfaat hutang sebagai pelindung keuangan bagi perusahaan, karena ketika penggunaan hutang sangat tinggi maka biaya hutang yang dikeluarkan juga semakin tinggi, yang meningkatkan biaya agensi dan biaya kebangkrutan (Sherly dan Fitria, 2018).

Menurut Rachmitasari (2015), leverage berpengaruh positif terhadap penggelapan pajak. Keuntungan yang tinggi akan meningkatkan tingkat penggelapan pajak. Telah dikonfirmasi oleh peneliti Zahirah (2017) bahwa eksploitasi berpengaruh positif terhadap penggelapan pajak.

Perusahaan dengan beban pajak yang tinggi dapat menghemat pajak dengan meningkatkan hutang perusahaan. Peningkatan hutang menghasilkan tingkat bunga yang lebih tinggi yang dapat mengurangi arus kas perusahaan sebelum pajak, dan oleh karena itu mengurangi pajak yang harus dibayar perusahaan. Akibatnya, semakin tinggi tingkat suku bunga, semakin banyak keuntungan yang diperoleh perusahaan dalam bentuk pembayaran hutang dan suku bunga untuk meningkatkan penghindaran pajak perusahaan. Berdasarkan penjelasan yang telah dijabarkan, dapat dibuat hipotesis seperti dibawah ini :

H2 : Leverage berpengaruh positif terhadap tax avoidance

\subsection{Pengaruh Kepemilikan Institusional Ter- hadap Tax Avoidance}

Teori agensi (Agency theory) Jensen \& Meckling (1976) Hakim (2015) teori agensi berpendapat bahwa manajemen dan pemilik memiliki kepentingan yang berbeda. Perbedaan antara kepentingan pemilik dan manajemen tergantung pada peningkatan utilitas pemilik (pengelola), masalah dengan utilitas, kegunaan, dan imbalan yang diterima oleh pengelola.

Kepentingan yang berbeda menyebabkan konflik antara pemilik (pengelola) dan pengelola (penjual). Kepemilikan institusional diyakini dapat mencegah konflik kepentingan, karena kepemilikan institusional memiliki efek yang lebih baik dan lebih kuat daripada pemantauan budaya tata kelola. Dengan demikian, kepemilikan institusional perusahaan akan membantu memperkuat pengawasan untuk meningkatkan efisiensi manajemen, karena kedaulatan adalah sumber 
kekuatan yang dapat digunakan untuk mempertahankan atau memulihkan kekuasaan.

Menurut Feranik (2015), kepemilikan institusi memiliki pengaruh negative terhadap penghindaran pajak. Ketika kepemilikan perusahaan atas suatu perusahaan tumbuh, kecil kemungkinan bahwa manajer perusahaan akan menghindari pajak. Ini dikonfirmasi oleh peneliti Windarni et al. (2018) kepemilikan agensi tidak mempengaruhi penggelapan pajak.

Kepemilikan properti institusional perusahaan memainkan peran penting dalam pengendalian, disiplin dan pengaruh terhadap manajer. Saat kepemilikan lembaga ditetapkan, tindakan kebijakan akan membantu mengurangi beban perpajakan perusahaan. Adanya struktur kelembagaan kepemilikan sebagai sarana pengawasan pengelolaan terhadap kemungkinan tindakan yang dapat dilakukan pengelola, seperti melakukan tindakan untuk menghindari pajak. Berdasarkan premis tersebut, tuduhan bahwa hubungan antara independensi dan penghindaran pajak adalah buruk:

H3 : Kepemilikan institusional berpengaruh terhadap tax avoidance.

\subsection{Pengaruh Risiko Perusahaan Terhadap Tax Avoidance}

Dewi dan Sari (2015), risiko perusahaan berpengaruh negatif terhadap penggelapan pajak karena perusahaan yang berisiko tinggi cenderung mengungkapkan laporan keuangan karena perlu melihat seberapa baik perusahaan bekerja untuk menghindari peluang pengurangan pajak yang berlebihan. Hasil penelitian ini mendukung penelitian Budiman dan Setiyono (2012) serta Dewi dan Jati (2014) yang berpendapat bahwa perilaku pejabat memiliki pengaruh negatif terhadap penghindaran pajak, dan indikator kinerja dapat ditentukan oleh risiko perusahaan terhadap perusahaan.

Artinya dapat dijelaskan bahwa dengan tingkat risiko yang tinggi maka perusahaan akan menghasilkan pajak penghasilan yang lebih kecil, karena perusahaan dengan tingkat risiko yang tinggi akan menawarkan lebih banyak peluang, kerugian ketika perusahaan diharuskan membayar rugi pajak. Inilah sebabnya mengapa ada hubungan negatif antara risiko perusahaan dan penggelapan pajak. Seiring berkembangnya definisi di atas, hipotesis dikemukakan

H4: Corporate Risk berpengaruh pada Tax Avoidance

\subsection{Kualitas Audit Memoderasi Pengaruh Profitabilitas, Leverage, Kepemiikan In- stitusional, dan Risiko Perusahaan Ter- hadap Tax Avoidance}

Laporan keuangan yang direview oleh KAP The Big Four didasarkan pada kualitas review, yang mencerminkan nilai sebenarnya dari perusahaan, dengan asumsi bahwa perusahaan telah menyetujui KAP The Big Four (Price Water House Cooper - PWC, Deloitte Touche Tohmatsu, KPMG, Ernst \& Young E\&Y) lebih sedikit menipu dibandingkan perusahaan yang disurvei oleh KAP Non The Big Four (Annisa dan Lulus, 2012). Menurut Chai dan Liu (2010), jika tarif pajak terlalu tinggi akan memaksa perusahaan untuk menghindari pajak, sedangkan perusahaan yang paling penting dimintai pertanggungjawaban, sehingga perusahaan tampaknya tidak meraup keuntungan dari tujuan perpajakan. Oleh karena itu, semakin tinggi kualitas audit akan memoderasi pengaruh profitabilitas pada penggelapan pajak.

H5: Kualitas Audit Memoderasi Pengaruh Profitbilitas Terhadap Tax Avoidance

\subsection{Kualitas Audit Memoderasi Pengaruh Leverage Terhadap Tax Avoidance}

Penelitian Jihene dan Moez (2019) telah membuktikan bahwa kualitas audit sebagai variabel pemoderasi antara kompensasi dengan penghindaran pajak. Hasil ini menjelaskan bahwa perusahaan yang memanfaatkan hutang untuk meminimalkan beban pajaknya melalui tax avoidance akan dikontrol oleh audit yang berkualitas dari auditor eksternal, oleh karenanya manajemen perusahaan akan lebih memperhatikan 
pelaksanaan langkah-langkah penghindaran pajak dengan mengeluarkan kewajiban hutang. Berdasarkan penjelasan di atas, maka telah disusun hipotesis sebagai berikut

H6: Kualitas Audit Memoderasi Pengaruh Leverage Terhadap Tax Avoidance

2.7 Kualitas Audit Memoderasi Pengaruh Kepemilikan Institusional Terhadap Tax Avoidance

Penelitian Krisna (2019) menunjukkan bahwa kualitas audit dapat memitigasi dampak kepemilikan institusional terhadap penggelapan pajak. Hasil ini mendukung temuan Annisa dan Lulus (2012) bahwa Perusahaan yang disurvei oleh KAP The Big Four lebih sedikit penyimpangannya dibandingkan perusahaan yang diinvestigasi oleh KAP Non The Big Four (Annisa dan Lulus, 2012). Menurut Chai dan Liu (2010), jika hutang pajak terlalu tinggi maka akan memaksa perusahaan untuk menghindari pajak, dan akuntan akan lebih sadar bahwa perusahaan tidak akan mengelola produksi untuk keperluan perpajakan. Pengelolaan perusahaan saat ini akan lebih efektif setelah perusahaan mereview KAP The Big Four, sehingga kepemilikan institusional yang lebih tinggi dan kualitas audit yang lebih baik akan mengurangi praktik penggelapan pajak perusahaan

H7: Kualitas Audit Memoderasi Pengaruh Kepemilikan Institusional Terhadap Tax Avoidance

\subsection{Kualitas Audit Memoderasi Pengaruh Risiko Perusahaan Terhadap Tax Avoidance}

Manajemen perusahaan akan lebih memperhatikan manajemen perusahaan dan akan menghindari risiko bisnis yang sangat tinggi jika perusahaan tersebut diinvestigasi oleh spesialis yang berkualifikasi. Menurut Krisna et al (2019), auditor berkualitas tinggi cenderung menunjukkan teknik komputasi dan kekayaan yang tidak tepat dan mengarahkannya kepada mereka yang membutuhkannya, juga akurat dalam mengidentifikasi kesalahan material versus audit. kualitas rendah, sehingga kualitas pemeriksaan memungkinkan memblokir praktik penggelapan pajak. Berdasarkan uraian di atas, disusun hipotesis sebagai berikut

H8: Kualitas Audit Memoderasi Pengaruh Risiko Perusahaan Terhadap Tax Avoidance

\section{METODE PENELITIAN}

Metode yang diterapkan dalam penelitian ini ialah metode kuantitatif dan bentuk penelitian eksplanatif. Jenis penelitian eksplanatif ini juga merupakan penelitian yang memiliki tujuan untuk memperjelas hubungan antara mutasi relatif pada variabel lain dengan menggunakan analisis hipotetis (Cooper dan Schindler, 2014:141). Dalam penelitian memakai data dari perusahaan yang terdaftar di Bursa Efek Indonesia selama 3 tahun (20162018). Informasi tersebut diambil dari laporan keuangan perseroan yang dipublikasikan oleh Bursa Efek Indonesia. Menganalisis dampak profitabilitas, leverage, kepemilikan institusi dan risiko perusahaan terhadap penghindaran pajak dan tetap melindungi kualitas audit yang menjadi pemoderasi.

Ditinjau dari sisi pengamatan waktu, penelitian ini menggunakan data cross sectional dan time series. Cross sectional adalah dokumen yang dikumpulkan sekali untuk umum. Daftar deret waktu genap adalah data yang dikumpulkan secara terpisah dari waktu ke waktu. Jadi penelitian ini menggunakan daftar bacaan sebagai artikel silang dan artikel berseri (Nachrowi dan Usman, 2016).

Populasi menurut Cooper dan Schindler (2014:374) adalah kumpulan elemen yang ingin mereka simpulkan. Di sisi lain, seluruh jumlah populasi dalam penelitian ini merupakan jumlah perusahaan consumer goods yang terdaftar di Bursa Efek Indonesia 2016-2019.

Cooper dan Schindler (2014:91) mengemukakan sampel dinilai sebagai bagian dari populasi sasaran serta kategori ini harus dipilih dengan cermat untuk mewakilinya. Dalam penelitian ini, beberapa metode noninvasif digunakan untuk membuat model. Purposive sampling adalah proses pemodelan dengan istilah atau konsep yang ditetapkan oleh peneliti. Sampel dari penelitian ialah perusahaan consumer goods yang memenuhi kriteria seperti berikut. Perusahaan consumer 
goods yang menjadi sampel diharuskan dapat memenuhi kriteria seperti dibawah ini.

1. Perusahaan publik terdaftar Bursa Efek Indonesia periode 2016-2019.

2. Perusahaan consumer goods yang patuh dalam menerbitkan laporan keuangan periode 31 Desember 2016-2019.

3. Perusahaan consumer goods yang tidak mengalami kerugian pada periode 20162019.
4. Perusahaan consumer goods yang tidak mengalami delisting selama periode 20162019.

Variabel independel dalam penelitian ialah profitabilitas, leverage, kepemilikan institusional, dan risiko perusahaan. Sedangkan untuk yang menjadi variabel dependen adalah tax avoidance, serta kualitas audit sebagai variabel moderator. Berikut akan dijelaskan definisi dari masing-masing variabel

Tabel 3.1 Pengukuran Variabel

\begin{tabular}{|c|c|c|c|}
\hline Variabel & Dimensi & Pengukuran/Indikator & Skala Pengukuran \\
\hline Tax Avoidance & $\begin{array}{ll}\text { Effective } & \text { Tax } \\
\text { Rate } & \end{array}$ & $\begin{array}{l}\text { Beban pajak/Laba Sebelum Pa- } \\
\text { jak }\end{array}$ & Rasio \\
\hline Profitabilitas & ROA & Aba Bersih/Total Aset & Rasio \\
\hline Laverage & $\begin{array}{l}\text { Cash Interest } \\
\text { Coverage }\end{array}$ & Interest Expenses & Rasio \\
\hline $\begin{array}{l}\text { Kepemilikan Insti- } \\
\text { tusional }\end{array}$ & & Jumlah Kepemilikan saham & Rasio \\
\hline Resiko Perushaan & & Total Debt - Cash & Rasio \\
\hline Kualitas Auditor & $\begin{array}{l}\text { KAP The Big } \\
\text { Four }\end{array}$ & Dummy & Dummy \\
\hline
\end{tabular}

Model penelitian menggunakan variabel komparatif. Perbedaan antar variabel merupakan variabel spesifik yang memperkuat atau memperlemah hubungan antara variabel independen lain dengan variabel dependen (Ghozali, 2013). Analisis model regresi moderasi yang digunakan pada penelitian ini pure moderate. Uji pure moderate dilakukan dengan interaksi timbal balik, namun variabel mediator tidak berfungsi sebagai variabel independen. Jika perubahan integrasi melebihi nilai kritis yang telah ditentukan, yaitu 0.05 maka variabel moderasi bukan pure moderate. Dan sebaliknya, jika variabel interaksi dibawah nilai signifikan ( $=5 \%$ ) maka variabel moderasi adalah pure moderate.

Berikut ini adalah model regresi linear berganda untuk hipotesis 1, 2, 3 dan 4 :

$$
\begin{gathered}
\mathrm{TAX}=\beta 0+\beta 1 \mathrm{PRF}+\beta 2 \mathrm{LEV}+\beta 3 \mathrm{INS}+\beta 5 \mathrm{KA} \\
+\varepsilon \ldots \ldots(1)
\end{gathered}
$$

Model persamaan MRA untuk hipotesis 5, 6, 7 dan 8 :
$\mathrm{TAX}=\beta 0+\beta 1 \mathrm{PRF}+\beta 2 \mathrm{LEV}+\beta 3 \mathrm{INS}+\beta 4 \mathrm{RISK}$ $+\beta 5 \mathrm{KA}+\beta \mathrm{PRF} * \mathrm{KA}+\beta 67 \mathrm{LEV}$ $* \mathrm{KA}+\beta \mathrm{INS} * \mathrm{KA}+\beta \mathrm{INS} * \mathrm{KA}$ $+\varepsilon \ldots \ldots(2)$

Keterangan:

TAX $=$ Tax Avoidance

$\beta 0, \beta 1, \beta 2$,

$\beta 3, \beta 4, \beta 5$,

$\beta 6, \beta 7, \beta 8=$ Koefisien regresi variabel independen

PRF = Profitabilitas

LEV $\quad=$ Leverage

INS $\quad=$ Kepemilikan Institusional

RISK $=$ Risiko Perusahaan

KA $\quad=$ Kualitas Auditor

$\mathrm{PRF}^{*} \mathrm{KA} \quad=$ Interaksi antara variabel Profit dengan Kualitas Auditor

$\mathrm{LEV}^{*} \mathrm{KA}=$ Interaksi antara variabel Leverage dengan Kualitas Auditor

INS*KA = Interaksi antara variabel Kepemilikan Institusional dengan Kualitas Auditor 


$\begin{aligned} \text { RISK*KA }= & \text { Interaksi antara variabel } \\ & \text { Risiko Perusahaan dengan } \\ & \text { Kualitas Auditor } \\ \varepsilon & \text { Komponen error dari model }\end{aligned}$

\section{HASIL DAN PEMBAHASAN}

Hasil persamaan regresi terhadap signifikan koefisien dan interpretasi dari persamaan regresi tersebut adalah sebagai berikut:

a. Nilai konstanta (a) $=0,241$; yang menyatakan bahwa jika keberadaan profitabilitas, leverage, kepemilikan institusional, risiko perusahaan, profitabilitas dengan dimoderasi kualitas audit, leverage dengan dimoderasi kualitas audit, kepemilikan institusional dengan dimoderasi kualitas audit, dan risiko perusahaan dengan dimoderasi kualitas audit tidak ada atau bernilai 0 , maka tax avoidance akan bernilai 0,241, dimana faktor lain dianggap tetap.

b. Profitabilitas $(\mathrm{PRF})=-0.037$; yang berarti bahwa jika terjadi peningkatan pada variabel Profitabilitas (PRF) sebesar 1, maka tax avoidance (TAX) pada perusahaan Consumer Goods yang terdaftar di Bursa Efek Indonesia periode 2016-2019 akan mengalami penurunan sebesar 0.037, dimana faktor lain dianggap tetap.

c. Leverage $(\mathrm{LEV})=7.911 \mathrm{E}-5$; yang berarti bahwa jika terjadi peningkatan pada variabel Leverage (LEV) sebesar, maka tax avoidance (TAX) pada perusahaan Consumer Goods yang terdaftar di Bursa Efek Indonesia periode 2016-2019 akan mengalami kenaikan sebesar 7.911E-5, dimana faktor lain dianggap tetap.

d. Kepemilikan Institusional (KEPINS) $=0,027$; yang berarti bahwa jika terjadi peningkatan pada variabel Kepemilikan Institusional (KEPINS) sebesar1, maka tax avoidance (TAX) pada perusahaan Consumer Goods yang terdaftar di Bursa Efek Indonesia periode 2016-2019 akan mengalami kenaikan sebesar 0,027, dimana faktor lain dianggap tetap.

e. Risiko Perusahaan (RISK) =0,000; yang berarti bahwa jika terjadi peningkatan padaariabel Risiko Perusahaan (RISK) sebesar 1, maka tax avoidance (TAX) pada perusahaan
Consumer Goods yang terdaftar di Bursa Efek Indonesia periode 2016-2019 akan mengalami kenaikan sebesar 0,000, dimana faktor lain dianggap tetap.

f. Profitabilitas (PRF) dengan dimoderasi kualitas audit $(\mathrm{KA})=-0.183$; yang berarti bahwa jika terjadi peningkatan pada variabel Profitabilitas (PRF) dengan dimoderasi kualitas audit (KA) sebesar 1, maka tax avoidance (TAX) pada perusahaan Consumer Goods yang terdaftar di Bursa Efek Indonesia periode 2016-2019 akan mengalami penurunan sebesar 0.183, dimana faktor lain dianggap tetap.

g. Leverage (LEV) dengan dimoderasi kualitas audit $(\mathrm{KA})=-8.266 \mathrm{E}-5$; yang berarti bahwa jika terjadi peningkatan pada variabel Leverage (LEV) dengan dimoderasi kualitas audit (KA) sebesar 1, maka tax avoidance (TAX) pada perusahaan Consumer Goods yang terdaftar di Bursa Efek Indonesia periode 20162019 akan mengalami penurunan sebesar 8.266E-5, dimana faktor lain dianggap tetap.

h. Kepemilikan Institusional (KEPINS) dengan dimoderasi kualitas audit $(\mathrm{KA})=0.064$; yang berarti bahwa jika terjadi peningkatan pada variabel Kepemilikan Institusional (KEPINS) dengan dimoderasi kualitas audit (KA) sebesar 1, maka tax avoidance (TAX) pada perusahaan Consumer Goods yang terdaftar di Bursa Efek Indonesia periode 20162019 akan mengalami kenaikan sebesar 0.064, dimana faktor lain dianggap tetap.

i. Risiko Perusahaan (RISK) dengan dimoderasi kualitas audit $(\mathrm{KA})=-0.001$; yang berarti bahwa jika terjadi peningkatan pada variabel Risiko Perusahaan (RISK) dengan dimoderasi kualitas audit (KA) sebesar 1, maka tax avoidance (TAX) pada perusahaan Consumer Goods yang terdaftar di Bursa Efek Indonesia periode 2016-2019 akan mengalami penurunan sebesar 0.001, dimana faktor lain dianggap tetap.

$$
\begin{aligned}
& \text { Hasil Regresi Linear Berganda } \\
& \begin{aligned}
& \mathrm{TAX}=\beta 0+\beta 1 \mathrm{PRF}+\beta 2 \mathrm{LEV}+\beta 3 \mathrm{INS}+\beta 4 \mathrm{RISK} \\
&+\beta 5 \mathrm{KA}+\beta \mathrm{PRF} * \mathrm{KA}+\beta 67 \mathrm{LEV} \\
& * \mathrm{KA}+\beta \mathrm{INS} * \mathrm{KA}+\beta \mathrm{INS} * \mathrm{KA} \\
&+\varepsilon \ldots \ldots(2)
\end{aligned}
\end{aligned}
$$




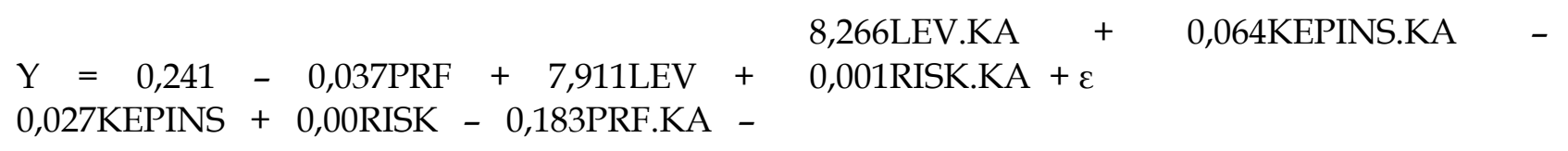

Tabel 4.1. Hasil Uji Hipotesis Partial

\begin{tabular}{|c|c|c|}
\hline Variabel & $\mathbf{t}$ & Sig. \\
\hline PRF & -0.782 & 0.438 \\
\hline LEV & 6.295 & 0.000 \\
\hline KEPINS & 1.136 & 0.261 \\
\hline RISK & 0.777 & 0.441 \\
\hline PRF_KA & -2.412 & 0.019 \\
\hline LEV_KA & -6.144 & 0.000 \\
\hline KEPINS_KA & 2.873 & 0.006 \\
\hline RISK KA & -1.911 & 0.061 \\
\hline
\end{tabular}

Selanjutnya untuk mengetahui signifikansi tiap komponen dalam persamaan diatas, dilakukan uji hipotesis.
Berikut adalah ringkasan hasil uji hipotesis yang didapatkan :

Tabel 4.2. Rangkuman Uji Hipotesis

\begin{tabular}{|c|c|}
\hline Hipotesis & Keterangan \\
\hline $\mathrm{H}_{1}$ : Pengaruh Profitabilitas Terhadap Tax Avoidance & Tidak Signifikan \\
\hline $\mathrm{H}_{2}$ : Pengaruh Leverage Terhadap Tax Avoidance & Signifikan \\
\hline $\mathrm{H}_{3}$ : Pengaruh Kepemilikan Institusional Terhadap Tax Avoidance & Tidak Signifikan \\
\hline $\mathrm{H}_{4}$ : Pengaruh Risiko Perusahaan Terhadap Tax Avoidance & Tidak Signifikan \\
\hline 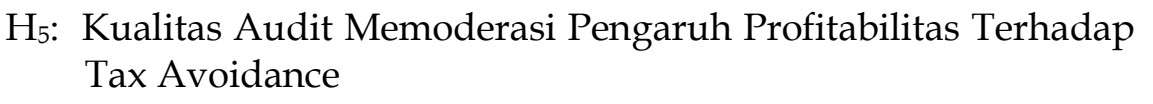 & Signifikan \\
\hline $\begin{array}{l}\mathrm{H}_{6}: \text { Kualitas Audit Memoderasi Pengaruh Leverage Terhadap Tax } \\
\text { Avoidance }\end{array}$ & Signifikan \\
\hline $\begin{array}{l}\mathrm{H}_{7}: \text { Kualitas Audit Memoderasi Pengaruh Kepemiikan Insti- } \\
\text { tusional Terhadap Tax Avoidance }\end{array}$ & Signifikan \\
\hline $\begin{array}{l}\mathrm{H}_{8}: \text { Kualitas Audit Memoderasi Pengaruh Risiko Perusahaan Ter- } \\
\text { hadap Tax Avoidance }\end{array}$ & Tidak Signifikan \\
\hline
\end{tabular}

Selanjutnya dibahas mengenai interpretasi hasil uji hipotesis tabel 4.2.

\section{1. Pengaruh Profitabilitas Terhadap Tax Avoidance \\ Sebab pengukuran penghindaran pajak} pada penelitian ini menerapkan ETR, dimana semakin tinggi nilai ETR berarti semakin rendah penghindaran pajak, serta sebaliknya semakin rendah nilai ETR berarti semakin tinggi penghindaran pajak. Maka arah hubungan tstatistik dapat di interprestasikan secara terbalik atau berlawanan.
Hasil hipotesis pertama menunjukkan bahwa profitabilitas tidak berp ngaruh terhadap tax avoidance pada Perusahaan Consumer Good yang terdaftar di Bursa Efek Indonesia periode 2016-2019. Semakin besar profitabilitas yang diperoleh perusahaan maka tingkat tax avoidance akan semakin rendah yang ditandai dengan semakin tingginya beban pajak yang dibayarkan. Perusahaan yang mempunyai laba tinggi akan memiliki kemampuan untuk membayar pajak dan menjaga reputasi perusahaan, sehingga perusahaan akan melaporkan pajaknya sesuai dengan peraturan 
yang berlaku dan meminimalkan tindakan tax avoidance.

Hasil ini sejalan dengan penelitian yang dilakukan Cahyono, Andini dan Raharjo (2016) yaitu profitabilitas tidak mempengaruhi penghindaran pajak. Namun juga ditemukan dari penelitian lain bahwa profitabilitas memeiliki pengaruh signifikan terhadap penghindaran pajak, keuntungan yang lebih tinggi akan mempengaruhi tingkat penghindaran pajak yang lebih tinggi. Dalam dunia korporasi hal ini dikembalikan kepada keputusan manajemen, apakah manajemen akan mengambil langkah-langkah untuk melakukan penghindaran pajak atau tidak.Lebih lanjut, hasil dari penelitian ini dapat dijelaskan bahwa perusahaan consumer goods tidak secara intensif melakukan praktik penghindaran pajak didukung oleh kondisi profitabilitas perusahaan yang cukup baik dengan rata-rata nilai ROE pada industry ini mencapai $12,76 \%$. Hal ini menunjukkan bahwa kemampuan perusahaan consumer goods menghasilkan laba atas ekuitas yang digunakan cukup efektif karena dapat memberikan imbal hasil sebesar $12,76 \%$ atas ekuitas yang digunakan. Karena perusahaan consumer goods memiliki profit yang cukup besar, maka manajemen lebih berkomitmen menjaga nama baik perusahaan dimata semua stekholders, sehingga kewajiban perpajakan termasuk kewajiban pajak penghasilan dibayarkan secara baik oleh perusahaan, atau dengan kata lain manajemen berusaha meminimalkan praktik penghindaran pajak yang berpotensi menimbulkan pemeriksaan oleh kantor paak, yang pada akhirnya mengurangi tingkat kepercayaan investor dan masyarakat terhadap perusahaan.

\section{2. Pengaruh Leverage Terhadap Tax Avoid- ance}

Hasil hipotesis kedua menunjukkan bahwa leverage berpengaruh signifikan terhadap tax avidance pada Perusahaan Consumer Good yang terdaftar di Bursa Efek Indonesia periode 2016-2019. Hasil ini menunjukkan bahwa semakin tinggi Leverage maka akan berdampak pada tingginya tindakan tax avoid- ance. Utang yang mengakibatkan munculnya beban bunga dapat menjadi pengurang laba kena pajak. Beban bunga yang dapat digunakan sebagai pengurang laba kena pajak adalah beban bunga yang muncul akibat adanya pinjaman kepada pihak ketiga.

Hasil hipotesis mendukung penelitian yang dilakukan oleh Rachmitasari (2015) yaitu leverage berpengaruh signifikan dan berhubungan negatif terhadap penghindaran pajak. Hasil yang sama juga ditunjukkan oleh Turyatin (2017) dan Zahirah (2017) bahwa leverage berpengaruh signifikan dan negatif terhadap penghindaran pajak.

Lebih lanjut, hasil penelitian ini menjelaskan bahwa leverage merupakan tingkat utang yang digunakan perusahaan dalam melakukan pembiayaan. Dimana semakin tinggi leverage dalam suatu perusahaan maka beban pajak yang ditanggung oleh perusahaan akan berkurang, sehingga langkah utang lebih dipilih oleh manajemen sebagai upaya menghindari beban pajak yang lebih besar. Meskipun tidak semua beban bunga dapat dibebankan terkait aturan yang ditetapkan oleh fiskus. Penelitian sebelumnya tentang pengaruh leverage terhadap penghindaran pajak dilakukan oleh Noor (2010) dan Barli (2018) yang menjelaskan bahwa perusahaan dengan jumlah utang lebih banyak memiliki tarif pajak yang efektif baik, hal ini berarti bahwa dengan jumlah utang yang banyak, upaya perusahaan untuk melakukan tax avoidance akan cenderung lebih kecil.

Hasil ini memberikan pemahaman bahwa semakin tinggi nilai dari rasio leverage berarti semakin tinggi jumlah pendanaan dari utang pihak ketiga yang digunakan perusahaan dan semakin tinggi pula biaya bunga yang timbul. Dengan adanya biaya bunga yang semakin tinggi akan memberikan pengaruh berkurangnya laba sebelum pajak perusahaan, maka hal tersebut memberikan pengaruh terhadap beban pajak perusahaan yang semakin rendah. Sehingga penggunaan utang oleh perusahaan dapat digunakan untuk penghematan pajak dengan memperoleh insentif berupa beban bunga yang akan menjadi pengurang penghasilan kena pajak. sehingga pihak manajemen 
akan memanfaatkan pembiayaan yang berasal dari utang agar laba perusahaan akan semakin kecil karena adanya biaya bunga yang besar maka menimbulkan beban pajak perusahaan akan menjadi rendah. Hasil penelitian in mendukung penelitian Calvin (2015) yang menyatakan bahwa leverage berpengaruh signifikan ke arah yang negatif terhadap CETR

\section{3. Pengaruh Kepemilikan Institusional Ter- hadap Tax Avoidance}

Hasil hipotesis ketiga memperlihatkan bahwa kepemilikan institusional terbukti tidak berpengaruh signifikan dan berhubungan negatif terhadap Tax Avoidance pada Perusahaan Consumer Good yang terdaftar di Bursa Efek Indonesia periode 2016-2019. Hasil hipotesis mendukung penelitian yang dilakukan oleh Dewi dan Sari (2015) yang membuktikan bahwa kepemilikan institusional tidak memiliki pengaruh pada tax avoidance. Hasil yang sama juga ditunjukkan oleh Susanto (2015); Turyatin (2017) bahwa kepemilikan institusional tidak berpengaruh terhadap tax avoidance.

Teori agensi (Agency theory) Jensen dan Meckling (1976) dalam Hakim (2015) teori agensi berpendapat bahwa manajemen dan pemilik memiliki kepentingan yang berbeda. Perbedaan antara kepentingan pemilik dan manajemen tergantung pada peningkatan utilitas pemilik (pengelola), masalah dengan utilitas, kegunaan, dan imbalan yang diterima oleh pengelola.

Kepentingan yang berbeda menyebabkan konflik antara pemilik dengan managemen. Kepemilikan institusional diyakini dapat mencegah konflik kepentingan, karena kepemilikan institusional memiliki efek yang lebih baik dan lebih kuat daripada pemantauan budaya tata kelola. Dengan demikian, kepemilikan institusional perusahaan akan membantu memperkuat pengawasan untuk meningkatkan efisiensi manajemen, karena kedaulatan adalah sumber kekuatan yang dapat digunakan untuk mempertahankan atau memulihkan kekuasaan.

Menurut Feranik (2015), kepemilikan institusi memiliki pengaruh negatif terhadap penghindaran pajak. Ketika kepemilikan perusahaan atas suatu perusahaan tumbuh, kecil kemungkinan bahwa manajer perusahaan akan menghindari pajak. Ini dikonfirmasi oleh peneliti Windarni et al. (2018) kepemilikan agensi tidak mempengaruhi penggelapan pajak.

Lebih lanjut, hasil penelitian ini menjelaskan bahwa hubungan kepemilikan institusional dengan penghindaran pajak bersifat negatif, yang berarti semakin tinggi kepemilikan institusional, maka semakin tinggi pula jumlah beban pajak yang harus dibayarkan oleh perusahaan. Hal ini dikarenakan semakin kecil kemungkinan praktik penghindaran pajak yang dilakukan oleh perusahaan. Pemilik institusional berdasarkan besar dan hak suara yang dimiliki, dapat memaksa manajer untuk berfokus pada kinerja ekonomi dan menghindari peluang untuk perilaku mementingkan diri sendiri. Hasil penelitian ini mendukung hasil penelitian yang dilakukan oleh Putrid dan Putra (2017) serta Puspitasari dan Ngadiman (2014) yang menyatakan bahwa variabel kepemilikan institusional memiliki hubungan yang negatif dan terhadap tax avoidance.

\section{4. Pengaruh Risiko Perusahaan Terhadap Tax Avoidance}

Hasil hipotesis keempat menunjukkan bahwa risiko perusahaan tidak berpengaruh signifikan dan berhubungan negatif terhadap tax avoidance pada Perusahaan Consumer Good yang terdaftar di Bursa Efek Indonesia periode 2016-2019. Hasil ini menjelaskan bahwa dengan tingkat risiko yang tinggi maka perusahaan akan menghasilkan pajak penghasilan yang lebih kecil, karena perusahaan dengan tingkat risiko yang tinggi akan menawarkan lebih banyak peluang, kerugian ketika perusahaan diharuskan membayar rugi pajak. Inilah sebabnya mengapa ada hubungan negatif antara risiko perusahaan dan penggelapan pajak.

Hasil hipotesis sejalan dengan penelitian yang dilakukan Budiman dan Setiyono (2012) juga Dewi dan Jati (2014) yang berpendapat jika per- 
ilaku pejabat mempunyai pengaruh negatif terhadap penghindaran pajak, dan indikator kinerja dapat ditentukan oleh risiko perusahaan terhadap perusahaan.

Lebih lanjut, dari hasil penelitian ini dapat dijelaskan bahwa penelitian ini mendukung penelitian yang dilakukan oleh Dewi dan Sari (2015) menunjukkan bahwa corporate risk berpengaruh negatif pada tax avoidance, hal ini disebabkan perusahaan yang memiliki risiko perusahaan yang tinggi cenderung akan menyajikan laporan keuangan apa adanya untuk melihat seberapa jauh kinerja yang telah dilakukan oleh perusahaan sehingga peluang untuk melakukan penghindaran pajak menjadi rendah. Budiman dan Setiyono (2012) serta Dewi dan Jati (2014) yang menyatakan bahwa karakter eksekutif berpengaruh negatif pada tax avoidance, karakter eksekutif dapat diketahui menggunakan risiko perusahaan (corporate risk) yang dimiliki perusahaan.

Hasil tersebut menunjukkan bahwa semakin tinggi tingkat risiko perusahaan maka akan membuat potensi pajak penghasilan yang akan dibayarkan oleh menjadi lebih kecil, karena perusahaan dengan tingkat risiko yang besar akan memberikan peluang yang cukup besar untuk mengalami kerugian, dimana dalam posisi rugi maka perusahaan tidak diwajibkan untuk membayar pajak. Hal inilah yang menjadi alasan mengapa terdapat hubungan negatif antara risiko perusahaan dengan penghindaran pajak.

\section{5. Kualitas Audit Memoderasi Pengaruh Profitabilitas Terhadap Tax Avoidance}

Hasil hipotesis kelima menunjukkan bahwa kualitas audit terbukti memoderasi pengaruh profitabilitas terhadap tax avoidance pada Perusahaan Consumer Good yang terdaftar di Bursa Efek Indonesia periode 20162019. Hasil ini menunjukkan bahwa laporan keuangan yang direvirew oleh KAP The Big Four memiliki kualitas audit yang baik dibandingkan dengan perusahaan yang disurvei oleh KAP non The Big Four. Sesuai dengan pendapat Chai dan Liu (2010), jika tarif pajak terlalu tinggi akan memaksa perusahaan untuk menghindari pajak, sedangkan perusahaan yang paling penting dimintai pertanggungjawaban, sehingga perusahaan tampaknya tidak meraup keuntungan dari tujuan perpajakan.

\section{6. Kualitas Audit Memoderasi Pengaruh Leverage Terhadap Tax Avoidance}

Hasil hipotesis enam menunjukkan bahwa kualitas audit terbukti memoderasi pengaruh leverage terhadap tax avoidance pada Perusahaan Consumer Good yang terdaftar di Bursa Efek Indonesia periode 2016-2019. Hasil hipotesis mendukung penelitian yang dilakukan oleh Jihene dan Moez (2019) yang membuktikan bahwa kualitas audit sebagai variabel pemoderasi antara hutang dengan penghindaran pajak. Hasil ini menjelaskan bahwa perusahaan yang memanfaatkan hutang untuk meminimalkan beban pajaknya melalui tax avoidance akan dikontrol oleh auditor yang berkualitas dari auditor eksternal, oleh karenanya manajemen perusahaan akan lebih memperhatikan pelaksanaan langkah-langkah penghindaran pajak dengan mengeluarkan kewajiban hutang.

\subsection{Kualitas Audit Memoderasi Pengaruh Kepemiikan Institusional Terhadap Tax Avoidance}

Hasil hipotesis ketujuh menunjukkan bahwa kualitas audit terbukti memoderasi pengaruh kepemilikan institusional terhadap tax avoidance pada Perusahaan Consumer Good yang terdaftar di Bursa Efek Indonesia periode 2016-2019. KAP The Big Four diasumsikan mampu mendeteksi praktek tax avoidance yang terjadi dalam perusahaan. Apabila kepemilikan oleh lembaga institusi tinggi maka akan mengurangi perilaku manajer yang mementingkan kepentingan pribadinya dibandingkan kepentingan perusahaan, perilaku manajer oportunistik ini yang dapat mendorongnya terjadinya tax avoidance. Adanya audit laporan keuangan oleh KAP The Big Four membuat manajemen lebih berhat-hati dalam melakukan tindakan yang mungkin merugikan perusahaan sehingga kualitas audit yang baik dengan kepemilikan institusional yang tinggi akan mengurangi kemungkinan tindakan tax avoidance. 


\section{8. Kualitas Audit Memoderasi Pengaruh Risiko Perusahaan Terhadap Tax Avoid- ance}

Hasil hipotesis kedelapan menunjukkan bahwa kualitas audit terbukti tidak memod rasi pengaruh risiko perusahaan terhadap tax avoidance pada Perusahaan Consumer Good yang terdaftar di Bursa Efek Indonesia periode 20162019. Dapat disimpulkan bahwa Auditor yang masuk dalam kategori KAP Big Four tidak dapat mempengaruhi Risiko perusahaan. semakin banyak keputusan yang diambil perusahaan melalui beberapa pihak dan pengawasan yang luas akan mempengaruhi keputusan yang diambil oleh pimpinan perusahaan tersebut. Pimpinan perusahaan yang risk averse lebih cenderung berhati - hati dalam mengambil keputusan yang berisiko bagi perusahaannya.

\section{SIMPULAN}

Berdasarkan hasil pengujian dan pembahasan yang telah dilakukan pada bab sebelumnya, maka dapat dibuatkan kesimpulan penelitian ini, Profitabilitas tidak berpengaruh tehadap tax avidance pada Perusahaan Consumer Good yang terdaftar di Bursa Efek Indonesia periode 2016-2019, Leverage berpengaruh signifikan terhadap tax avidance pada Perusahaan Consumer Good yang terdaftar di Bursa Efek Indonesia periode 2016-2019, Kepemilikan institusional tidak berpengaruh terhadap tax avidance pada Perusahaan Consumer Good yang terdaftar di Bursa Efek Indonesia periode 2016-2019., Risiko perusahaan tidak berpengaruh terhadap tax avidance pada Perusahaan Consumer Good yang terdaftar di Bursa Efek Indonesia periode 2016-2019., Kualitas audit terbukti memoderasi pengaruh profitabilitas terhadap tax avoidance pada Perusahaan Consumer Good yang terdaftar di Bursa Efek Indonesia periode 2016-2019, Kualitas audit terbukti memoderasi pengaruh leverage terhadap tax avoidance pada Perusahaan Consumer Good yang terdaftar di Bursa Efek Indonesia periode 2016-2019, Kualitas audit terbukti memoderasi pengaruh kepemilikan institusional terhadap tax avoidance pada Perusahaan Consumer Good yang terdaftar di Bursa Efek Indo- nesia periode 2016-2019 dan Kualitas audit terbukti tidak memoderasi pengaruh risiko perusahaan terhadap tax avoidance pada Perusahaan Consumer Good yang terdaftar di Bursa Efek Indonesia periode 2016-2019

Implikasi hasil dari penelitian ini bagi akademisi adalah Sebaiknya manajemen perusahaan melakukan perencanaan pajak yang terukur dari sisi risiko dan kemungkinan potensi pemeriksaan atas pajak penghasilan, hal ini dapat dilakukan dengan mempertimbangkan rasio wajar antara beban pajak dengan laba bersih perusahaan dibandingkan rata-rata industri sejenis. Faktor yang paling utama penting untuk diperhatikan dalam melakukan perencanaan pajak adalah kebijakan posisi hutang perusahaan atau rasio leverage dan memperhatikan peran dan kualitas dari pihak eksternal dalam hal ini khususnya kualitas audit. peneliti Sebaiknya menambahkan variabel independen lain yang dapat mempengaruhi tax avoidance seperti ukuran perusahaan, umur perusahaan dan lain sebagainya. Disarankan untuk memakai sektor lainnya selain sektor Consumer Good dengan jumlah sampel dan populasi yang lebih banyak serta terdaftar di Bursa Efek Indonesia. Dan sebaiknya perusahaan berhatihati dengan tindakan tax avoidance yang dapat merugikan negara dan membuat reputasi perusahaan menjadi buruk di mata publik.

\section{REFERENSI}

Amelia, M. V., Pratomo, D., dan Kurnia. (2017). The Influence of Institutional Ownership and Manajerial Ownership with Control Variables Firm Size and Leverage on Tax Avoidance. E-Proceeding of Management, Vol.4, No.2 Agustus, Page 1510, ISSN : 2355-9357.

Annisa, A.N. dan Kurniasih, Lulus. (2012). Pengaruh Corporate Governance terhadap Tax Avoidance. Jurnal Akuntansi dan Auditing, Vol. 8, hal 95-189.

Arianandini, P. W., dan Ramantha, I. W. (2018). Pengaruh Profitabilitas, Leverage, dan Kepemilikan Institusional Pada Tax Avoidance. E-Jurnal Akuntansi Universitas Udayana, Vol.22.3. Maret : 2088-2116, 
ISSN: 2302-8556.

Armstrong. C. S., Blouin, J. L., Jagolinzer, A. D., dan Larkcer, D. F. (2015). Corporate Governance, Incentives, and Tax Avoidance. Journal Of Accounting And Economics, 60 (1), 1-17.

Barli, harry. (2018). pengaruh leverage dan firm size terhadap penghindaran pajak. jurnal ilmiah akuntansi universitas pamulang. vol. 6, no. 2, juli

Budiman, Judi dan Setiyono. 2012. Pengaruh Karakter Eksekutif Pada Penghindaran Pajak (Tax Avoidance). Universitas Islam Sultan Agung, Semarang.

Cahyono, D. D., Andini, R. dan Raharjo, K. (2016). Pengaruh Komite Audit, Kepemilikan Institusional, Dewan Komisaris, Ukuran Perusahaan (SIZE), Leverage (DER) dan Profitabilitas (ROA) Terhadap Tindakan Penghindaran Pajak (Tax Avoidance) Pada Perusahaan Perbankan Yang Listing BEI Periode Tahun 2011-2013. Journal of Accounting, Vol 2 (No. 2).

Calvin Swingly dan I Made Sukartha. 2015. Pengaruh Karakter Eksekutif, Komite Audit, Ukuran Perusahaan, Leverage dan Sales Growth Pada Tax Avoidance. EJurnal Akuntansi Universitas Udayana 10.1 (2015): 47-62

Charisma, R.B., dan Dwimulyani, S. (2019). Pengaruh Struktur Kepemilikan Terhadap Tindakan Penghindaran Pajak Dengan Kualitas Audit Sebagai Variabel Moderating. Prosiding Seminar Nasional Pakar ke 2 Tahun 2019 Buku 2: Sosial dan Humaniora.

Damayanti, F. dan Susanto, T. (2015). Pengaruh Komite Audit, Kualitas Audit, Kepemilikan Institusional, Risiko Perusahaan dan Return on Assets Terhadap Tax Avoidance. Jurnal Bisnis Dan Manajemen, Vol. 5, No. 2, Oktober.

Dewi, G. A. P. dan Sari, M. R. (2015). Pengaruh Insentif Eksekutif, Corporate Risk dan Corporate Governance Pada Tax Avoidance. E-Jurnal Akuntansi Universitas Udayana, 13. 1 : 50-67, ISSN: 2302-8556.
Dewi, K. dan Jati, I. K. (2014). Pengaruh Karakter Eksekutif, Karateristik Perusahaan, dan Corporate Governance pada Tax Avoidance di Bursa Efek Indonesia. EJurnal Akuntansi, ISSN 2302-8556 6.2: 249260.

Dewi, Ni Nyoman Kristiana dan Jati, I Ketut. 2014. Pengaruh Karakter Eksekutif, Karakteristik Perusahaan, dan Dimensi Tata Kelola Perusahaan Yang Baik Pada Tax Avoidance di Bursa Efek Indonesia. Skripsi. Fakultas Ekonomi Universitas Udayana, Bali.

Dewinta, Ida Ayu Rosa dan Setiawan, Putu Ery. (2016). Pengaruh Umur Perusahaan, Return On Asset Dan Leverage Terhadap Tax Avoidanc. E-Jurnal Akuntansi Universitas Udayana. Vol 6, No. 2: 249-260.

Dr. Widarto Rachbini dan Prof. Dr. Didik J. Rachbini. (2020). Metode Riset Ekonomi $\mathcal{E}$ Bisnis: Analisis Regresi-SPSS \& SEM-Lisrel. Jakarta: INDEF.

Fahmi, Irham. (2014). Analisis Laporan Keuangan. Bandung: Alfabeta.

Faizah, Nur Siti dan Vidya Vitta Adhivina. (2017). Pengaruh Return On Asset, Leverage, Kepemilikan Institusional dan Ukuran Perusahaan Terhadap Tax Avoidance. Jurnal Akuntansi, Vol.5 No.

Feranika, A. (2015). Pengaruh Kepemilikan Institusional, Dewan Komisaris Independen, Kualitas Audit, Komite Audit, Karakter Eksekutif dan Leverage terhadap Tax Avoidance. Jurnal Akuntansi dan Keuangan Unja, Vol. 4, No. 1.

Ghozali, Imam. (2013). Aplikasi Analisis Multivariate dengan Program IBM SPSS 21 Update PLS Regresi. Semarang: Badan Penerbit Universitas Diponegoro.

Hakim, A. R. (2015). Pengaruh Aktiva Pajak Tangguhan dan Beban Pajak Tangguhan Terhadap Manajemen Laba. Sekolah Tinggi Ilmu Ekonomi Indonesia. Surabaya.

Handayani, Rini. (2017). Pengaruh Return on Assets (ROA), Leverage dan Ukuran Perusahaan Terhadap Tax Avoidance Pada Perusahaan Perbankan yang Listing di BEI Periode Tahun 2012-2015. Jurnal Akuntansi Maranatha, Vol 10, No. 1, pp. 
72-84.

Janrosl, Viola Syukrina E dan Dian Efriyenti. (2018). Analisis Pengaruh Ukuran Perusahaan, Leverage Dan Profitabilitas Terhadap Tax Evoidance Pada Bank Riau Kepri Tbk. Seminar Nasional Ilmu Sosial dan Teknologi 1, ISBN: 978-602-52829-0-4.

Jihene, F. dan Moez, D. (2019). The Moderating Effect of Audit Quality on Ceo Compensation and Tax Avoidance: Evidence From Tunisian Context. International Journal of Economics And Financial Issues, 9 (1), 131-139. ISSN: 2146-4138.

Kasmir. (2014). Analisis Laporan Keuangan, Edisi Pertama, Cetakan Ketujuh. Jakarta: PT. Rajagrafindo Persada.

Krisna, A. M. (2019). Pengaruh Kepemilikan Institusional dan Kepemilikan Manajerial pada Tax Avoidance Dengan Kualitas Audit Sebagai Variabel Pemoderasi. Wacana Ekonomi, 18.

Kushariadi, Briska dan Rosyid Nur Anggara Putra. (2018). Good Corporate Governance, Leverage, Ukuran Perusahaan dan Tax Avoidance. Journal of Islamic Finance and Accounting, Vol. 1, No. 2.

Maharani, I., dan Suardana, K. A. (2014). Pengaruh Corporate Governance, Profitabilitas dan Karakter Eksekutif Pada Tax Avoidance Perusahaan Manufaktur. EJurnal Akuntansi Universitas Udayana, Vol. 6 No. 2, 525-539.

Nabilla, S. S., dan Fikri, Z. I. (2018). Pengaruh Risiko Perusahaan, Leverage (Debt To Equity Ratio) dan Pertumbuhan Penjualan Terhadap Penghindaran Pajak (Tax Avoidance). Seminar Nasional Cendekiawan, 1179-1182.

Nachrowi, Djalal Nachrowi, dan Hardius Usman. (2016). Pendekatan Populer dan Praktis Ekonometrika untuk Analisis Ekonomi dan Keuangan. Jakarta: Badan Penerbit Universitas Indonesia.

Ngadiman, dan Puspitasari, C. (2014). Pengaruh Leverage, Kepemilikan Institusional, dan Ukuran Perusahaan terhadap Penghindaran Pajak (Tax Avoidance) pada Perusahaan Sektor Manufak- tur yang Terdaftar di Bursa Efek Indonesia 2010-2012. Jurnal Akuntansi, Vol 18, No 3, Halaman 408- 421.

Okrayanti, T. Y., Utomo, S. W., \& Nuraina, E. (2017). Pengaruh Karakteristik Perusahaan Dan Corporate Governance Terhadap Tax Avoidance (Studi Pada Perusahaan Manufaktur Di BEI). Forum Ilmiah Pendidikan Akuntansi, Vol 5 (No.1) Oktober 2017, 804-817.

per, Donal R dan Scindler, Pamela S (2014). Busines Research Methods. The MC GrowHill Lumpanies: Singapore.

Pitaloka, S., dan Merkusiwati, N. K. (2019). Pengaruh Profitabilitas, Leverage, Komite Audit, dan Karakter Eksekutif terhadap Tax Avoidance. E-Jurnal Akuntansi Universitas Udayana, Vol. 27, No. 2, 1202-1230.

Prakosa, K. B. (2014). Pengaruh Profitabilitas, Kepemilikan Keluarga, dan Corporate Governance terhadap Penghindaran Pajak di Indonesia. Simposium Nasional Akuntansi XVII.

Putri, Vidiyanna Rizal dan Bella Irwasyah Putra. (2017). Pengaruh Leverage, Profitability, Ukuran Perusahaan Dan Proporsi Kepemilikan Institusional Terhadap Tax Avoidance. Daya Saing Jurnal Ekonomi Manajemen Sumber Daya, Vol. 19, No. 1.

Rachmitasari, A. F. (2015). Pengaruh Return On Assets, Leverage, Corporate Governance, Ukuran Perusahaan dan Kompensasi Rugi Fiskal Pada Tax Avoidance (Perusahaan Manufaktur yang terdaftar di Bursa Efek Indonesia). Jurnal Universitas Muhammadiyah Surakarta.

Rozak, Tresna Syah et al. (2018). Pengaruh Profitabilitas, Likuiditas, Dan Leverage Terhadap Tax Avoidance (Studi Empiris pada Perusahan Manufaktur Sektor Aneka Industri yang terdaftar di Bursa Efek Indonesia periode 2013-2017). Program Studi Akuntansi Fakultas Ekonomi Universitas Pakuan.

Saputra, M. D. R dan Asyik, N. R. (2017). Pengaruh Profitabilitas, Leverage dan Corporate Governance Terhadap Tax Avoidance. Jurnal Ilmu dan Riset 
Akuntansi, Vol 6, No 8, 2017.

Sari (2018). Pengaruh corporate governance, ukuran perusahaan, kompensasi rugi fiskal, dan struktur kepemilikan terhadap tax avoidance. Jurnal Akuntansi dan Auditing, 8(2), 2-23.

Setijaningsih. (2012). Teori Akuntansi Positif dan Konsekuensi Ekonomi. Jurnal Akuntansi Volume XVI, No. 03 September 2012. Universitas Tarumanegara Jakarta.

Sherly, Elvis Nopriyanti dan Desi Fitria. (2018). Pengaruh Penghindaran Pajak, Kepemilikan Institusional, Dan Profitabilitas Terhadap Biaya Hutang (Studi Empiris Pada Perusahaan Manufaktur Yang Terdaftar Di BEI Periode 2011- 2015). Ekombis Review.

Sulistiono, E. (2018). Pengaruh Profitabilitas, Leverage, dan Kualitas Audit Terhadap Tax Avoidance. Jurnal Informasi Perpajakan, Akuntansi Dan Keuangan Publik. Vol. 13 No. 1 Januari: 87-110, ISSN : 2685-6441.

Susanti. (2018). Pengaruh moral pajak, diskriminasi pajak, teknologi dan informasi perpajakan terhadap penggelapan pajak (studi kasus pada wajib pajak orang pribadi di wilayah kpp pratama kebayoran lama). Universitas Pamulang, Tangerang Selatan.

Tristianto, D. dan Oktaviani, R. M. (2016). Faktor-Faktor Yang Mempengaruhi Tax Avoidance Dengan Leverage Sebagai Variabel Mediasi. Dinamika Akuntansi, Keuangan dan Perbankan. Mei 2016, Hal: 65- 81. Vol. 5, No. 1, ISSN :1979-4878.

Turyatin. (2017). The Analysis of Tax Avoidance Determinant on The Property and
Real Estate Companies. Jurnal Dinamika Akuntansi, Vol. 9, No. 2, September, PP. 143-153, P-ISSN 2085-4277, E-Issn 25026224.

Wardani, Aditya Kusuma., Anggra, Eva., dan Amirah. (2019). Pengaruh Karakteristik Perusahaan, Good Corporate Governance (GCG), dan Corporate Social Responsibility (CSR) Terhadap Penghindaran Pajak (Tax Avoidance). Garuda, Vil. 7, No. 2.

Wijayanti, Y. Carrica dan Merkusiwati, Ni Ketut L. A. (2017). Pengaruh Proporsi Komisaris Independen, Kepemilikan Institusional, Leverage, Dan Ukuran Perusahaan Pada Penghindaran Pajak. E-Jurnal Akuntansi, Vol. 20, No. 1.

Windarni, N., Nurlaela, S., dan Suhendro. (2018). Pengaruh Kepemilikan Institusional, Proporsi Dewan Komisaris Independen, Komite Audit, Pertumbuhan Penjualan dan Leverage Terhadap Tax Avoidance. Seminar Nasional dan Call for Paper.

Yunita Valentina dan Dina Anggraini. (2019). Peran Komisaris Independen, Ukuran Perusahaan, Kinerja Keuangan dan Leverage Terhadap Usaha Penghindaran Pajak. E-Journal Akuntansi, Vol.26, No.2, Februari, 1601-1631.

Zahirah, Azizah. (2017). Pengaruh Leverage, Kepemilikan Institusional, Kepemilikan Manajerial Dan Ukuran Perusahaan Terhadap Penghindaran Pajak (Studi Pada Perusahaan Manufaktur Yang Terdaftar Di BEI Periode 2013-2015). JOM Fekon, Vol. 4 No. 1 